\title{
Teachers' Level of Knowledge of Reading and Content Area Reading Instruction
}

\author{
Winicel May C. Ancheta \\ Ph.D Professor, School of Arts, Sciences and Education, Divine Word College of Laoag, Ilocos \\ Norte, Philippines \\ winicelancheta@dwcl.edu.ph
}

DOI: http://doi.org/ 10.36892/ijlls.v4i1.802

$\begin{array}{ll}\begin{array}{l}\text { Received: } \\ \text { 04/01/2022 }\end{array} & \begin{array}{c}\text { Abstract } \\ \text { The content area teachers' competencies were determined using a descriptive } \\ \text { Accepted: }\end{array} \\ \text { research methodology based on their level of knowledge of the nature of reading } \\ \text { and content area reading instruction. Data were collected using the Assessment } \\ \text { Tool on Teachers' Level of Knowledge of the Nature of Reading and Content } \\ \text { Area Reading Instruction. To enhance the answers acquired from the survey } \\ \text { Keywords: } & \text { questionnaire, unstructured interviews were used. Frequency count and mean } \\ \text { content area reading } & \text { were used to evaluate and interpret data gathered from teacher-respondents' } \\ \text { instruction, reading, } & \text { level of knowledge of the nature of reading and content area reading } \\ \text { content area } & \text { instruction. Generally, the teacher-respondents were found to be moderately } \\ \text { teachers. } & \text { knowledgeable of the nature of reading and content area reading instruction. } \\ & \text { The common issues in content area reading instruction include teachers' lack } \\ & \text { of knowledge and skills, insufficient number of content area reading instruction } \\ & \text { training activities available for teachers, and resistance to implement and } \\ & \text { integrate reading instruction and strategies. }\end{array}$

1. INTRODUCTION

The ability to read is regarded as one of the most significant academic language abilities among students. This skill is thought to help students in coping with life's trials and tribulations as well as the ongoing changes in society brought on by technological breakthroughs. The relevance of reading has been highlighted in literature for the past quarter century in the context of content areas.

Conforming to Fang and Coatoam (2013), content area reading looks at literacy and general methods like summarizing, querying, and inferring that can help students understand and are universally applicable across disciplines. All teachers, even content area teachers, must be reading teachers as a result of this strategy. However, it is sad to note that when K to 12 teachers are asked to identify the challenges students face in learning, one of the major issues often discussed is that students find it difficult to comprehend the texts that are used in their classrooms. These difficulties are even pronounced for students in grades 4 to 12 , where more than eight million students are hard up in understanding texts in academic content areas (Fang \& Schleppegrell, 2010).

The school system in the Philippines is in a bind due to a widespread and rapid drop in linguistic abilities, particularly in reading. As a result of poor student performance in mathematics and scientific exams both at home and abroad, the quality of Philippine education has been in peril for the past decade. With the introduction of the K-12 curriculum, the government's attempts to upset the status quo failed miserably (Imam, 2016).

As a matter of fact, Akut and Abejuela (2020) underscored that the country is still in desperate need of graduates who are completely prepared for the international labor market and proficient in the use of current technology. The People Management Association of the 
Philippines (PMAP) said that four out of 10 fresh graduates and young applicants are turned down for jobs because they lack critical thinking, initiative, and good communication skills.

Teaching content area reading in high school is not seen as a method of transmitting content because high school content area teachers think their primary obligation to students is to convey content (Razak et al., 2020). Heller (2018) backed up this argument, claiming that few middle and high school teachers receive more than a token amount of reading instruction training and that few consider themselves as reading teachers. Instead, most secondary school teachers see themselves as subject matter experts in subjects like biology, history, and algebra. She also pointed out that even English teachers who are believed to be in charge of reading instruction tend to define themselves first and primarily as literary teachers.

Since the integration of reading education in subject-area studies was called to action, teachers have developed what is known as resistance to content reading instruction. According to researchers, teachers' reluctance is due to instructional time constraints, teachers' lack of confidence in their knowledge and preparation to teach reading skills, teachers' beliefs that reading skills cannot be related to content teaching, and the fact that teachers confuse readingto-learn with learning-to-learn and perceive reading instruction as basic skills instruction.

Reading experts, on the other hand, argue that learning to read does not begin at the primary level. Secondary school teachers must understand that they are more than teachers of facts, figures, dates, and processes if the nation's children are to advance beyond the basics of reading. That is, content-area teachers should not become reading teachers; rather, they should stress reading habits relevant to their topics, allowing students to read like historians, mathematicians, scientists, and other specialists in their fields (Shanahan, 2012).

In McCoss-Yergian and Krepps' (2010) study, which aimed to determine whether teacher attitudes towards literacy instruction influenced literacy strategy implementation in subject areas, it was discovered that teacher attitudes towards literacy instruction in the content area predicts the probability that teachers will implement reading instruction in their subject areas. On the attitude scale, 74 percent of teachers believed that teaching reading skills in their subject areas was a waste of their teaching time. Subject teachers had a skewed view of their competence to teach reading (McCoss-Yergian \& Krepps, 2010).

According to Hock (2013), it is a mistake to believe that literacy challenges can only be treated within a reading, English or language arts class. Furthermore, research has shown that students gain significant reading skills when explicit, teacher-directed approach instruction is applied. As a result, classroom teachers' attitudes toward content area literacy may be one of the most important elements influencing secondary students' reading achievement and practice (Moreillon, 2011).

On a positive side, Olson and Gee (2007) interviewed 47 secondary classroom teachers from school districts in southwest Texas about the approaches they employ in assisting students learn to read expository texts between 2007 and 2011 about their expertise with and usage of content area reading strategies. Using the first six tactics that provide exceptional aid for teachers were regarded as the best six in this study, which included previewing topics and terminology, manipulations, retelling, individual or class summary, visualization, and brainstorming.

Fritz and his colleagues (2011) also looked into pre-service and in-service teachers' perceptions of study strategy instruction's use, usefulness, and efficacy. 104 people responded to an open-ended questionnaire in this study. The most often mentioned tactics were active and intentional reading, identifying significant material, note keeping, time management, and critical listening/reading/thinking, according to the findings.

Reading comprehension can be greatly improved when it is explicitly taught, according to research (Paris \& Hamilton, 2009; Yassin et al., 2019). Furthermore, according to Pressley (2011), education in how to apply reading techniques is required to improve comprehension because meaning does not exist in text but must be built by the reader from the text. Teachers should employ reading strategies to improve students' comprehension of texts (Fang \& 
Coatoam, 2013). These include providing effective vocabulary instruction; teaching students reading comprehension strategies that can help them make sense of content-area texts; designing reading assignments that are likely to motivate students who are not participating in school activities; and teaching students to read in ways that are unique to their own content areas.

The researcher, who is a teacher in English for more than 11 years, can attest to the deteriorating reading comprehension skills of students across the curriculum. This alarming scenario is indeed attributed not only to students' lack of knowledge and interest towards reading but also to content areas teachers' low competencies on content area reading instruction.

It is in this context that the researcher was encouraged to determine the content area teachers' competencies along their level of knowledge of the nature of reading and content area reading instruction. It is hoped that the results of this study could be the basis in the development of intervention programs or materials that can increase the teachers' competencies towards the implementation and integration of reading strategies in the content areas.

\section{LITERATURE REVIEW}

The Nature of Reading. Reading is essential for all learning, both in general and in language acquisition. Knowledge and information are critically important in today's society. There is a steady stream of information from a variety of sources, including conventional sources such as books, newspapers, and magazines, as well as more modern digital sources (Afflerbach, 2012). It's critical to be able to browse these resources and find what you're looking for. In addition to just comprehending the written text and its words, phrases, structure, and genres, this necessitates a variety of abilities, including the capacity to navigate through the text overflow, read multi-medially, digitally, and intertextually. It is vital to have the ability to understand, integrate, and combine information from many sources in a knowledge society.

Reading, according to Braten (2010), is frequently described as an interactive activity in which the author and the reader collaborate to achieve comprehension. In a collaborative effort, the author must formulate the content in such a way that it is interpretable, while the reader must mobilize the skills and knowledge required to comprehend it. The reader, on the other hand, is the most likely to sabotage the process by failing to comprehend, giving in, and stopping reading. As a result, the reader is regarded as the most important factor in comprehension.

Evidently, today's readers have high expectations. Comprehension is also required to completely understand a text - to engage with it and add meaning to it, one must engage with it and add meaning to it. Reading is all about putting letters and words together to form words, phrases, and sentences. According to Roe (2014), reading comprehension is the ability to make meaning of what is read. In addition, reading takes place in context, and the meaning of a book is determined by the reader's existing knowledge as well as the techniques by which he or she approaches it, according to Cook (2010). This indicates that deciphering letters and words isn't enough; what is read must also be enriched with knowledge and relevance.

Reading is crucial, and all teachers must take it into account. Assuming reading is taken into account entails acknowledging that the most important aspects of reading are: creating meaning from text; reading texts on screen or paper with concentration, endurance. fluency, and coherence; engaging in texts; comprehending, applying what is read; reflecting on text types and functions; processing and comprehending texts based on prior knowledge.

Nature of Content Area Reading Instruction. Reading is an important part of topic area literacy (Bean, Readence, \& Baldwin, 2012), which is required to read, comprehend, and respond to suitable instructional materials in a certain subject area. Whether at school or in the business, the ability to extract information and meaning from texts is a core skill for all learning. Student failure to grasp strategies for reading content-area texts will result in a shortfall in their 
ability to be successful, autonomous learners, which will have a substantial impact on their success after high school. Teachers achieve their educational goals while giving students the opportunity to become strategic readers and critical thinkers through content-area reading teaching (Heller, 2018).

Shrum (2016) provided an outline on the rationale of content area reading instruction. First, students do not automatically transfer reading skills to content areas. Second, teachers can identify essential concepts, critical vocabulary, text elements, and reading-thinking skills that students need to learn in their topic because they are experts in their fields. Third, content teachers can role-play and model the abilities their students need to apply and develop, igniting student interest in their subjects. Fourth, it is the job of the teacher to assist students in learning the reading methods they require to comprehend certain content materials and concepts. Fifth, the teacher identifies specific reading-thinking skills as important for students to understand their topic when modelling and teaching reading via content, rather than teaching phonics or other basic word attack skills. Sixth, content area reading entails assisting students in making connections between what they already know (previous knowledge) and what is being given (academic vocabulary). Seventh, content teachers must teach their students how to think and learn in their subject through reading. Eighth, content teachers do not become reading specialists but become teachers who teach their students how to read their specific content and include vocabulary development, comprehension strategies, fluency practice, and writing strategies. Ninth, to comprehend content area reading materials, students must be able to determine the meanings of general (words that students know and use as part of everyday activities), specialized (words that have specific meanings for content area subjects), and technical (words that relate specifically to each content area or topic) vocabulary, all of which are found in each content area. Finally, reading and writing go hand in hand.

According to many teachers, reading to learn is not the same as learning to read. Students learning to read usually focus on the pronunciation and comprehension of narrative texts. Comprehension of these narratives frequently does not need competency in literary criticism or interpretation, despite teachers' desire for literal, inferential, and evaluative/applied understanding. While reading for learning focuses on the comprehension and use of largely factual texts in subjects such as history and science, reading for learning also includes a mixture of English informational and literary materials.

In order to learn, one must have discipline knowledge. Knowing how literary critics think about and debate literature can help students interpret and discuss a literary piece more effectively while reading it. When reading a history text, students benefit from understanding how historians gather and analyze information and write about historical events. Studying science necessitates distinct understandings than mastering history, literature, or any other discipline (Afflerbach and Pearson, 2012).

Reading competence, without a doubt, has a significant impact on students' futures, determining their post-secondary education, work choices, and general lifestyles. Most students with poor literacy abilities are condemned to be undereducated and underemployed as a result of unfulfilling, low-paying vocations and unfulfilled personal goals, whereas kids with strong reading skills have many educational and employment options. For pupils to master the material of the subjects they teach and become independent readers and learners, teachers must consider reading skills and adopt reading techniques.

Status of Content Area Reading Instruction in the Philippines. Reading, mathematics, and science are essential disciplines of basic school curriculum in the Philippine education system. However, due to low performance of students in mathematics and scientific assessments both locally and internationally during the previous decade, the quality of Philippine education has been called into doubt. The government's current efforts to embrace K-12 curriculum did not do much to shift the status quo at first (Imam, 2016).

According to Nolasco (2010), the number of Filipinos aged 10 to 64 who do not understand what they read has increased to 20.1 million people. In the 2008 Functional 
Literacy, Education, and Mass Media Survey, the most recent numbers were used. Moreover, the article pointed out that Filipinos' counting and understanding skills are still poor and shockingly low. The number of people who are unable to count or comprehend has increased. This was due to a larger population base in 2008, with 67 million people compared to 57.6 million in 2003. Those who lack comprehension abilities, on the other hand, climbed from 19.6 million in 2003 to 20.1 million in 2008.

This is consistent with the United Nations Development Report 2009, which shows that, despite the fact that the Philippines has the world's highest literacy rate, at 93.4 percent in 2008, Filipino students' performance in international Mathematics and Science tests has remained poor, with local students struggling to pass. The National Achievement Test (NAT) performance of students was even more dismal. In 2003-2005, one million fourth-year students had less than $2 \%$ knowledge in science and only $10 \%$ mastery in mathematics, according to the National Assessment of Teachers (NAT) (Imam, 2016). For the four years following (20082011), students' NAT in both elementary and secondary schools fell below the 75 percent mastery standard.

Poor reading, according to Luz (2010), leads to poor learning. Science and math studies in high school demands a degree of reading skill because much of what is learned is self-taught. Experimentation is supposed to be at the heart of the scientific classroom experience. Basic science facts and theory should be acquired in preparation for this. Most knowledge is passed from teacher to student in the old-school rote learning style since much of what is learned is neither self-driven nor internalized. As a result, Filipino schoolchildren have low reading rates. As a result of their lack of preparation, very few high school graduates are equipped for university-level science, as well as the lack of a technical/technology culture among our working people. Without it, this country's manufacturing and technical sectors will remain poor, explaining our lack of competitiveness in the global economy to a considerable part.

Low reading, whether in English or the national language, is a reflection of poor linguistic abilities. This can be noticed right away in the language proficiency of public school teachers. In response to the reality that English language proficiency was severely lacking or declining among Filipinos of all ages, then-Education Secretary Edilberto de Jesus launched a nationwide campaign to improve the language proficiency of public school teachers, beginning with high school teachers, in 2003.

A Self-Assessment Test in English (SATE) was administered to nearly 53,000 secondary teachers teaching English, science, and math - languages that demand a high level of English communication abilities - to measure their competence level. Only one-fifth (19\%) of those who passed with a score of at least 75 percent correct did so successfully. While the vast majority of test takers were able to correctly answer more than half of the questions $(65 \%)$, nearly one-fifth were clearly illiterate and should not have been teaching courses that need some level of English communication abilities in reading and writing. A grade of $75 \%$ or more is regarded "mastery," while a grade between $50 \%$ and $75 \%$ is considered "nearing mastery," and a grade below 50\% is deemed "no mastery."

A strong need has emerged among Filipino educators to strengthen content area reading instruction in the country, not only to improve student performance on national examinations, such as the NAT, but also to assist teachers in improving their pedagogy through the integration of effective reading strategies in their content areas, based on the findings presented.

Reasons for Overlooking Content Area Reading Instruction. The traditional practice of relegating reading instruction to the elementary grades is misguided and outdated in today's technological era. Because the basic decoding and comprehension skills required in elementary school are only the beginning of effective, efficient reading, literacy support must be evident in all grades and across all content areas.

As per Joseph and Schisler (2016), students will have problems in secondary contentarea classes if these talents are not formed in the early grades and they are compelled to employ a reading-to-learn strategy. Students will not develop higher-level reading and thinking skills 
unless they master their entry-level methods as beginning readers and then polish them in following grades through specific content-area reading instruction, supervised practice, and meaningful interaction with the content (Bell, 2014). Few high schools offer advanced reading programs because students are expected to learn advanced reading strategies on their own, despite the fact that cognitive demands of informative textbooks deliver sophisticated material loads that exceed the competence level of many secondary students.

The main reason why content area reading instruction is not emphasized at the secondary level is because of the teachers' perspective. Because their topic is the most significant in the classroom, secondary teachers regard themselves as content specialists rather than reading teachers (D'Arcangelo, 2012). Teaching does not recognize the usefulness of reading as a learning tool, which is demonstrated by the fact that their assessments emphasize conversations and lectures over mandatory readings, which they express to students.

When asked to integrate reading strategies in their content lesson, they respond as if they were being asked to teach additional content, suggesting that they are unaware of the link between content and learning process. Because teachers are under pressure to cover an everexpanding amount of knowledge from textbooks that students cannot or do not read in order to prepare them for state assessment tests, their point of view may be accurate. Content-area teachers must use instructional strategies to encourage literacy within their content area rather than teaching literacy, which is the truth (Jacobs, 2012).

Content area teachers rarely use content area teaching strategies (McKenna \& Robinson, 2016). Teachers are supposed to teach reading to students who require it the most, notwithstanding their lack of understanding. The opposition to integrating reading instruction into academic settings, as well as the opposition of secondary teachers to becoming reading instructors, is widely documented. In-service instructors rarely implement content literacy practices in their classrooms, according to a large body of research over the last 20 years (Moje, 2012). Many middle school teachers have long maintained that reading and other literacy components should be taught in the language arts or English departments (Mallette et al., 2012).

The source of teachers' resistance towards the content area literacy may be explained by teachers' acceptance of integrating reading and writing in their instruction as to teach an additional content (Jacobs, 2012) or they may see these strategies as time consuming and not particularly efficient. When Moje (2012) asked teachers to write about their reading nightmares, their classroom successes with reading, their unanswered questions, and their wishes to get rid of their reading nightmares, he discovered that little has changed over the years and nightmares have gotten worse, and that teachers felt betrayed and frustrated because they did not receive formal reading knowledge in their teacher education training.

Secondary content-area reading teaching has been undervalued due to society's notion that literacy acquisition ends in childhood, allowing society to underestimate adolescent education while focusing on childhood and adult literacy. This viewpoint denies that reading is necessary for content learning, despite the fact that literacy requirements rise as children progress from elementary to middle and high school. Students in their content-area classes require intensive teaching and regulated practice to meet these academic challenges and be prepared for life after high school.

\section{METHODOLOGY}

Research Design. The study employed the descriptive research design. According to Ethridge (as cited in Antonio, 2018), descriptive research seeks to describe the current status of an identified variable. It is characterized as simply the attempt to determine, describe or identify what is all about the variables.

Locale of the Study. The study was conducted in the three schools divisions in the Province of Ilocos Norte, Philippines, namely the Schools Division of Ilocos Norte, City Schools Division of Laoag, and City Schools Division of Batac.

Population and Sampling. The target population of this study were the junior high school content area teachers of the public schools in the three schools divisions of Ilocos Norte. 
To have a number representative of all junior high school content area teachers in the three schools divisions, the sample size was determined using Slovin's formula. Using a 5\% margin of error, the computed sample size (n) was approximately equal to 262.14 which was rounded to 262 . Hence, 262 junior high school content area teachers were considered as actual sample size of this study. Moreover, to ensure that all junior high school content area teachers from the three schools divisions were given fair chances of becoming part of this study, proportionate stratified random sampling method was used. The number of respondents to be taken from each content area in the three school divisions was determined using a sampling percentage, with each stratum treated as a single stratum regardless of population size discrepancies. The sampling technique was set at 34 percent to ensure that the data was sufficient. This means that for this study, 34 percent of the population of junior high school teachers in each of the three school divisions were taken as respondents.

Instrumentation and Data Collection Procedure. This study used a surveyquestionnaire, Assessment Tool on Teachers' Level of Knowledge of the Nature of Reading and Content Area Reading Instruction. Attached to the survey-questionnaire was a letter indicating provision for the teacher-respondents' full consent in their participation in the study and that all disclosed information would be held with utmost confidentiality. The survey questionnaire was in a rating scale. Since the questionnaire was devised by the researcher based on her bibliographical research, a panel of experts in research validated it.

In scoring the responses to the items in this survey, the following scale was used:

Scale
5
4
3
2
1

\author{
Descriptive Interpretation \\ Very Highly Knowledgeable (VHK) \\ Highly Knowledgeable (HK) \\ Moderately Knowledgeable (MK) \\ Slightly Knowledgeable (SK) \\ Not Knowledgeable (NK)
}

The research instrument was tried out by eight teachers of Sanchez Mira National High School. Two teachers for each content area were involved in the try-out. The results indicated that the respondents clearly understood the items in the survey questionnaire. Thus, no modifications were made.

For the data collection procedures, the researcher wrote a formal letter of request addressed to the Schools Division Superintendent (SDS) of Laoag City, signifying the study's intention. Upon the approval of the SDS, the copies of the first instrument were sent through Google Form. In compliance with the approved letter in conducting the study from SDOIN, the researcher coordinated with the school heads before administering the online surveyquestionnaire. The researcher gave the teacher-respondents two weeks or more time to complete the survey-questionnaires before submitting them, making sure that no school activity was disrupted.

The data gathering was conducted with ethical considerations in mind. Throughout the course of this study, the respondents' rights were protected or safeguarded. The respondents were given an explanation of the study, as well as the potential benefits. It was highlighted that their willingness or will to participate in the study would determine their involvement. Nonetheless, they were asked to give their informed consent.

The results of the survey-questionnaire were supplemented by unstructured interviews. The teacher-respondents' responses to the unstructured interviews were summarized and tabulated to identify common problems in content area reading instruction.

Tools for Data Analysis. Data obtained from the teacher-respondents' level of knowledge of the nature of reading and content area reading instruction were analyzed and interpreted using frequency count and mean.

The following statistical ranges with their corresponding descriptive interpretations were used to describe the teacher-respondents' level of knowledge of the nature of reading and content area reading instruction: 


$\begin{array}{cll}\text { Scale } & \text { Range Interval } & \text { Descriptive Interpretation } \\ 5 & 4.51-5.00 & \text { Very Highly Knowledgeable (VHK) } \\ 4 & 3.51-4.50 & \text { Highly Knowledgeable (HK) } \\ 3 & 2.51-3.50 & \text { Moderately Knowledgeable (MK) } \\ 2 & 1.51-2.50 & \text { Slightly Knowledgeable (SK) } \\ 1 & 1.00-1.50 & \text { Not Knowledgeable (NK) }\end{array}$

\section{RESULTS AND DISCUSSION}

It can be gleaned from the table that only the English teacher-respondents are highly knowledgeable $(\bar{x}=3.53)$ of the nature of reading and content area reading instruction. In accordance with Republic Act (RA) No. 7722, otherwise known as the "Higher Education Act of 1994," teachers in English are expected to have sufficient knowledge and skills in reading instruction because they received relevant training and preparation in this area during their undergraduate years in pursuit of an outcomes-based quality assurance system as advocated under CMO No. 30 series of 2004.

In accordance with Republic Act (RA) No. 7722, otherwise known as the "Higher Education Act of 1994," teachers in English are expected to have sufficient knowledge and skills in reading instruction because they received relevant training and preparation in this area during their undergraduate years in pursuit of an outcomes-based quality assurance system as advocated under CMO No. 30 series of 2004 .

Table 1. Teacher-respondents' level of knowledge of the nature of reading and content area reading instruction $(n=258)$. 


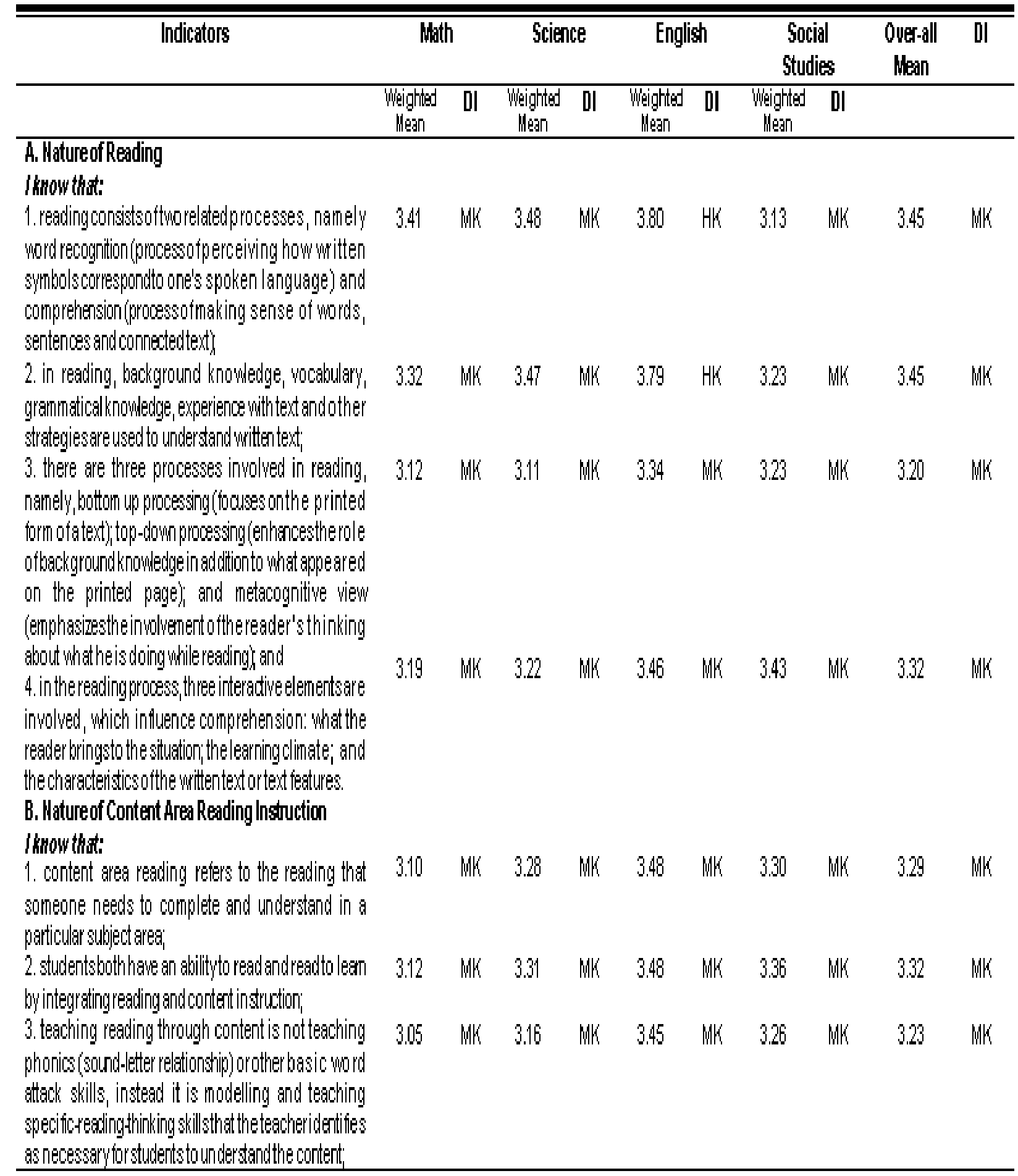


Table 1 continued...

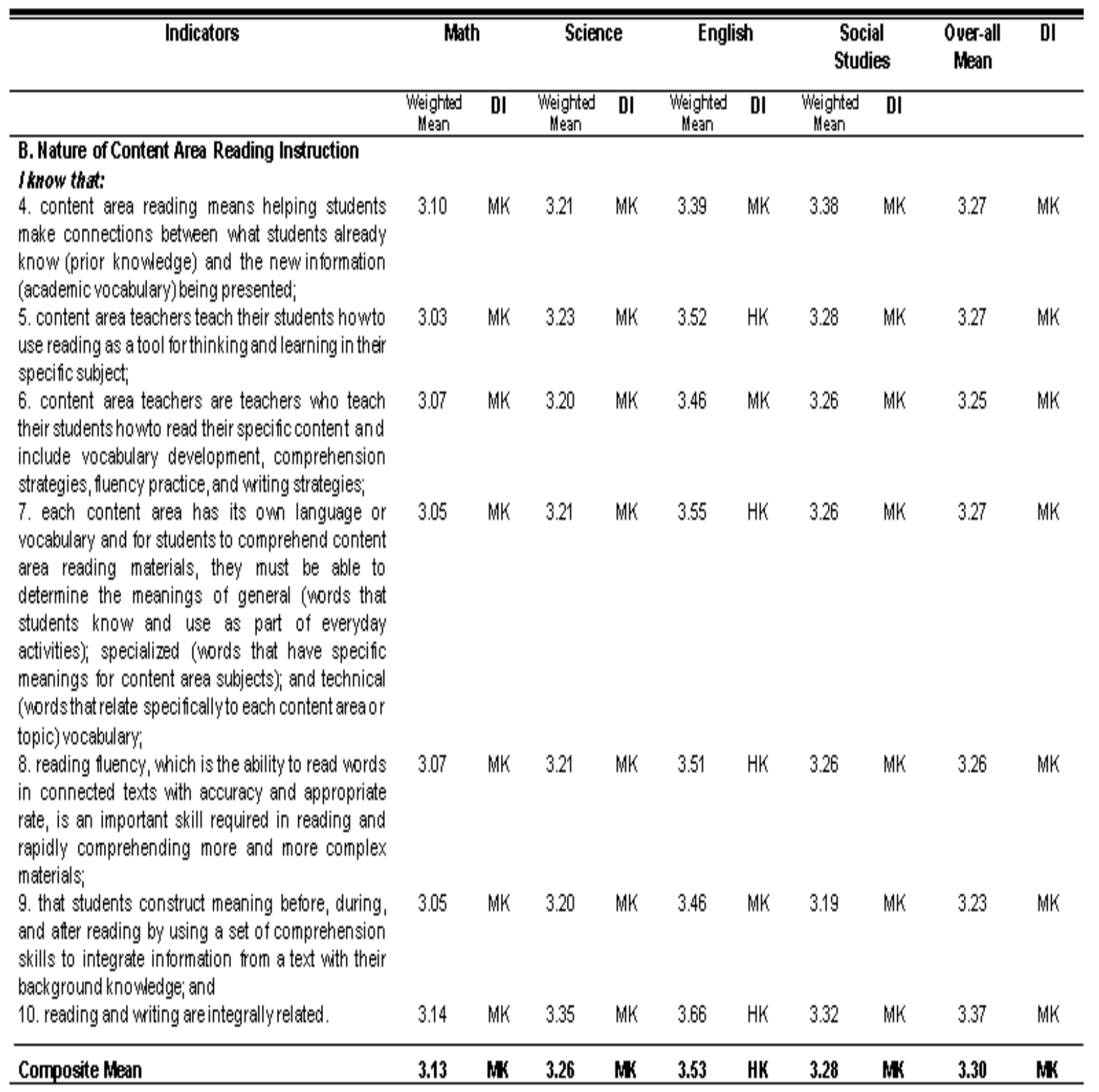

However, while all BSEd students take courses related to communication skills, including reading, those who major in English take more courses related to these skills, allowing them to gain a broad reading background in language and literature, demonstrate competence in using innovative language and literature teaching approaches, methodologies, and strategies, as well as demonstrate proficiency in reading.

On the nature of reading and content area reading teaching, the Mathematics teacherrespondents have the lowest composite mean (3.13) as seen in the table. The findings support Kenney's (2015) contention that unless Mathematics instructors are generalists and have received reading instruction training, literacy is not considered a component of their skill set. She affirmed that Mathematics teachers are unaware that reading a Mathematics text or problem is fundamentally different from other types of reading, necessitating unique strategies. 
Overall, the table shows that the teacher-respondents are moderately knowledgeable at all indicators, with an overall composite mean of 3.30. The highest rating was obtained on the items, reading consists of two related processes, namely word recognition (process of perceiving how written symbols correspond to one's spoken language) and comprehension (process of making sense of words, sentences and connected text), with a mean of 3.45 (Moderately Knowledgeable), and in reading, background knowledge, vocabulary, grammatical knowledge, experience with text and other strategies are used to understand written text, with a mean 3.45 (Moderately Knowledgeable).

On the other hand, their lowest rating was received by the item, there are three processes involved in reading, namely, bottom up processing (focuses on the printed form of a text); top-down processing (enhances the role of background knowledge in addition to what appeared on the printed page); and metacognitive view (emphasizes the involvement of the reader's thinking about what he is doing while reading), with a mean of 3.20 (Moderately Knowledgeable).

Content area teachers lack sufficient knowledge of the critical components for content area reading instruction, namely vocabulary development, comprehension strategies, fluency practice, and reading strategies, according to the findings of Washburn (2011).

Furthermore, the data reinforce those of previous studies that found gaps in teachers' knowledge of language and literacy development, as well as essential components of reading instruction (McCombes-Tolis \& Feinn, 2008).

These findings are supported by the responses made by the teacher-respondents during the unstructured interviews. When asked about their knowledge of the nature of content area reading instruction, some of the teacher-respondents gave the following remarks:

"Haan (No). I am not really knowledgeable when it comes to the reading and teaching reading because when I was in college, I only have [sic] one subject that focus [sic] on reading. The subject only provided an overview about reading." - Social studies-teacher-respondent 257

"I know something about reading strategies, but often, I use the easiest and fast [sic] way in delivering the lesson because of time constraints. " - Science-teacherrespondent 112

"I am interested more [sic] being expert in my own content area. I am focus [sic] more on teaching my content rather than teaching my students how to be reading." - Math-teacher-respondent 3

"I recognize the importance of considering the reading styles and needs of students. Unfortunately, I do not have vast information how to do it." - Math-teacherrespondent 11

"I know little about the different reading approaches or models, namely topdown, bottom-up, and metacognition. I hope seminars on content-area reading strategies would be conducted, too." - Social studies-teacher-respondent 245

"Basta ammo ta ubing ti ag-solve ken ag-compute, mayaten. (As long as the student knows how to solve and compute, that is enough." - Math-teacher-respondent 21

Content area teachers fail to implement reading strategies in the delivery of their lessons because they did not receive formal knowledge of reading in their teacher education training, as per the teacher-respondents' responses. Furthermore, his research shows that teachers have never had personal 
experience with reading teaching and are overwhelmed by the fact that they are supposed to teach both topic and reading.

Despite their mastery of reading, content area teachers often lack the ability to develop and apply their own knowledge and abilities in a way that allows them to deliver successful instruction to their pupils. The term assumptive teaching was coined by Herber (2011) to describe what teachers do when they unconsciously assume their students know how to read and learn, as well as the motivation and interest to do so. Instead, these teachers frequently expect their students to be fluent in processing reading material, making inferences, and reading critically, as well as to have a quick grasp of the reading materials they are given to understand.

Furthermore, most teachers barely spent $1 \%$ of their time on comprehension instruction (Durkin, 2012). Time was spent assigning tasks for 15 percent of the time and assessing comprehension for 18 percent of the time, largely through teacher-directed questioning. Students worked on assignments during the remaining time. Students should be taught to use reading strategies actively, integratively, and flexibly, according to Pressley (2011), who also concluded that there was insufficient instruction in comprehension strategies in schools.

This concept of assumptive teaching is reflected in the following statements of some teacher-respondents:

"We have to follow an overload [sic] curriculum. Teachers have time limitations. I try, but kaadwan (usually), I don't have enough time for reading activities. Hence, all students are expected to read frequently. Reading is the most basic skill. How can a student be successful if he don't [sic] understand what he read [sic]?" - Math-teacher-respondent 8

"I believe that since students are already in high school, they're expected to have the skills needed in understanding a particular reading material." - Social studies-teacher-respondent 250

"Nu kayatda ti makaadal, ammoda dapat nu kasanu awaten ti basbasaenda a haanda kasapulan ti tulong ti teachers da. (If students want to learn, they should know how to learn with little assistance from their teachers. ") - Science-teacher-respondent 83

"The teaching guide has too much content to cover. It is designed for 60minute class periods. Most of the time, I assign my students to read materials on their own. They have to learn how to learn, so they can be prepare to face bigger and more difficult tasks when they will be in the tertiary education. " - English-teacherrespondent 160

Content area teachers have developed a reluctance to include reading teaching into content areas due to their lack knowledge and skills in this area. Teachers rarely use content literacy strategies in their classrooms, according to Moje (2012). According to Mallette et al. (2015), many middle-school teachers have historically felt that the duty for reading and other components of literacy education lies with the language arts or English teachers. Teachers' opposition to reading instruction in the content area could be characterized by their acceptance of integrating reading and writing into their education as an additional material (Jacobs, 2012), or they may regard these tactics as time-consuming and inefficient (Moje, 2012).

Some of the teacher-respondents exhibit the reluctance to integrate reading instruction into content areas as manifested in the following statements:

"My task is to deliver and teach my content. What is important is that my students develop mathematical skills and competencies." - Math-teacher-respondent 45 
"My primary role is to teach my subject matter. Teaching students how to read and comprehend is the main responsibility of language teachers." - Science-teacherrespondent 89

"If I use reading strategies in my class, it will take so much of the classroom time. I might not be able to tackle the main aspect of the lesson." - Social Studiesteacher-respondent 211

"Teaching our students [sic] to read is really the responsibility of the Filipino and English teachers." - Math-teacher-respondent 15

"Most of the time, dakami nga agisursuro iti English ken Filipino ti mababalaw no nababa ti scores ti ubbing ti NAT kada NCAE. (Most of the time, we, teachers in English and Filipino, are blamed for the low scores obtained by students in NAT and NCAE.) This is sad because I believe that every teacher, whatever your major is, has the responsibility to help students read and comprehend." - Englishteacher-respondent 130

Content area teachers have developed a reluctance to include reading teaching into content areas due to their lack knowledge and skills in this area. Teachers rarely use content literacy strategies in their classrooms (Moje, 2012). Mallette et al. (2015) underscored that many middle-school teachers have historically felt that the duty for reading and other components of literacy education lies with the language arts or English teachers. Teachers' opposition to reading instruction in the content area could be characterized by their acceptance of integrating reading and writing into their education as an additional material (Jacobs, 2012), or they may regard these tactics as time-consuming and inefficient (Moje, 2012). Pressley (2011) also concluded that students should be taught to apply reading techniques actively, integratively, and flexibly.

The findings suggest that they need to improve and expand their understanding of the important components of reading education, including word recognition, vocabulary development, previous knowledge building, fluency, making meaning, and comprehension. Teachers require additional information and training to help their pupils to be capable of processing reading materials, making inferences, and reading critically (Richardson, Morgan, \& Fleener, 2009).

\section{Conclusion}

Based on the findings, the content area teachers are not adequately equipped with knowledge of the nature of reading and content area reading instruction. Common problems in content area reading instruction were determined by the researcher through the conduct of the unstructured interviews. These include lack of knowledge and skills, limited or insufficient training activities available for teachers along content area reading instruction, the need to deliver the content, and resistance in the implementation and integration of reading instruction and strategies along their content areas.

The findings of this study would enable the teachers to assess and reflect on their professional strengths and developmental needs and concerns toward content reading strategies. This study can also help them determine specific programs, crash courses or training activities that they need to undergo in order to further enhance their knowledge and skills on reading strategies for content areas.

\section{References}

Afflerbach, P., Paris, S.G., \& Pearson, P. (2012). Clarifying differences between reading skills and reading strategies. The Reading Teacher, 61(5), pp. 365-33. 
Akut, K., \& Abejuela, A. (2020). Developing Reading Competencies of College Students Using Blended Instruction. International Journal of Language and Literary Studies, 2 (3), pp. 230-242. https://doi.org/10.36892/ijlls.v2i3.348

Antonio, G.C. (2018). Training program for secondary school mathematics teachers based on the framework for mathematics teacher education. Unpublished Doctoral Dissertation. Divine Word College of Laoag, Laoag City.

Bean, T.W., Readence, J.E., \& Baldwin, R.S. (2012). Content area literacy: An integrated approach, (9th ed.). Dubuque, Iowa: Kendall/Hun.

Blintz, W. (2011). Exploring reading nightmares of middle and secondary school teachers. Journal of adolescent \& adult literacy, 41(1), pp. 12- 24. Braselton.

Braten, I. (2010). Reading comprehension. Reading in the knowledge society - theory and practice. Oslo: Cappelen Academy.

Cook, V. (2010). Using the first language in the classroom. Canadian Modern Language Review, 57(3): pp 402-23.

D'Arcangelo, M. (2012). The challenge of content-area reading. Educational Leadership 60.3, pp. 12-5.

Fang, Z., \& Coatoam, S. (2013, May). Disciplinary literacy: What you want to know about it. Journal of Adolescent \& Adult Literacy, 56(8), pp. 627-632.

Fang, Z., \& Schleppegrell, M. (2010, April). Disciplinary literacies across content areas: Supporting secondary reading through functional language analysis. Journal of Adolescent \& Adult Literacy, 53(7), pp. 587-597.

Heller, R. (2018). Teaching reading and writing in the content areas. WETA Washington, D.C.

Herber, H. (2011). Research within reach: Secondary school reading. Newark: University Press.

Hock, M.F. \& Deshler, D. (2013). No child leaves behind teen reading proficiency. The Education Digest. 69.4, pp. 27-35.

Imam, O. (2016). Effects of reading skills on students' performance in science and math in public and private secondary schools. Journal of Education and Learning. Vol. 10 (2), pp. 177-186.

Fritz, A. E., Cooner, D., \& Stevenson, C. (2011). Training new content area secondary teachers to teach literacy: The university/public school partnership. Reading Improvement, 46(1), pp. 19-28.

Jacobs, V.A. (2012). Reading, writing, and understanding. Educational Leadership. 60.3, pp. 58-61.

Joseph, L. M, \& Schisler R.A. (2016). Reading and the whole student. Principal Leadership, 6.6: $11-5$.

Kenney, J.M. (2015). Literacy strategies for improving mathematics instruction. Association for Supervision and Curriculum Development.

König, J. (2012). Teachers' pedagogical beliefs: current and future research. In Johannes König (Ed.), Teachers Pedagogical Beliefs. pp. 7-14, Munster: Waxmann Verlag GmbH.

Luz, J.M. (2010). A nation of nonreaders. Retrieved from http://pcij.org/stories/a-nation-ofnonreaders/

Mallette, M. H., Henk, W. A., Waggoner, J. E., \& DeLaney, C. J. (2015). What matters most? A survey of accomplished middle-level educators' beliefs and values about literacy. Action in Teacher Education, 27(2), pp. 33-42.

McKenna, M. C., \& Robinson, R. D. (2016). Teaching through text: Reading and writing in the content areas (4th ed.). Boston, MA: Pearson/Allyn \& Bacon.

McCombes-Tolis, J., \& Feinn, R. (2008). Comparing teachers' literacy- related knowledge to their state's standards for reading. Reading Psychology, 29, pp. 236-265.

McCos-Yergian, T., \& Krepps, L. (2010). Do teacher attitudes impact literacy strategy implementation in content area classrooms? Journal of Instructional Pedagogies , 4, pp. $1-18$. 
Moje, E. B. (2012). Foregrounding the disciplines in secondary literacy teaching and learning: A call for change. Journal of Adolescent \& Adult Literacy, 52, pp. 96- 107.

Moreillon, J. (2011). Collaborative strategies for teaching reading comprehension maximising your impact. Chicago: American Library Association.

Nolasco, R. (2010). Reforms first or K+12 means nothing. Philippine Daily Inquirer.

Olson, M. W., \& Gee, T. C. (2007). Content reading instruction in the primary grades: Perceptions and strategies. The Reading Teacher, 45, pp. 298-307.

Paris, S.G. \& Hamilton, E.E. (2009). The development of children's reading comprehension. In SE Israel \& GG Duffy (eds). Handbook of Research on Reading Comprehension. New York: Routledge.

Pressley, M. (2011). Comprehension instruction: what makes sense now, what might make sense soon. Reading Online, 5. Retrieved from http://www.readingonline.org/articles/art_index.asp?HREF=/articles/handbook/pressley /index.html

Razak, N. A., Yassin, A. A., \& Maasum, T. N. R. T. M. (2020). Formalizing informal CALL in learning english language skills. In Enhancements and limitations to ICT-based informal language learning: emerging research and opportunities (pp. 161-182). IGI Global.

Richardson, J. S., Morgan, R. F., \& Fleener, C. (2009). Reading to learn in the content areas (7th ed.). Belmont, CA: Wadsworth Cengage Learning.

Roe, A. (2014). Reading Education-after the first reading instruction. Oslo: University Press.

Shanahan, T. \& Shanahan C. (2008). Teaching disciplinary literacy to adolescents: Rethinking content area literacy. Harvard Education Review. 78(1), pp. 40-59.

Shrum, N. (2016). Teaching reading in the content areas: If not me, then who? CI3T Summer Conference.

Stewart, R., \& O'Brien, D. G. (2013). Resistance to content area reading: A focus on preservice teachers. Journal of Reading, 32, 396-401.

Washburn, E.K. (2011). Teacher knowledge of basic language concepts and dyslexia. Annals of Dyslexia, 17, pp. 165 -183.

Yassin, A. A., Razak, N. A., \& Maasum, N. R. M. (2019). Investigating the need for computer assisted cooperative learning to improve reading skills among Yemeni university EFL students: a needs analysis study. International Journal of Virtual and Personal Learning Environments (IJVPLE), 9(2), 15-31.

\section{AUTHOR'S BIO}

Winicel May C. Ancheta, PhD is a Master Teacher I at Currimao National High School, Schools Division of Ilocos Norte, Philippines. She has been teaching for more than 11 years. She finished her Doctor of Philosophy, major in Development Education, at Divine Word College of Laoag, where she also serves as a part-time professor at the Graduate School. She was a recipient of the Fulbright Scholarship - Foreign Language Teaching Assistant Program at Skyline College in San Bruno, California, USA from August 1, 2017 to June 2, 2018. 